\title{
PENGEMBANGAN MODUL BIOLOGI MATERI ANIMALIA MELALUI PEMBELAJARAN BERBASIS MASALAH UNTUK MENINGKATKAN KETERAMPILAN BERPIKIR TINGKAT TINGGI
}

\author{
Cornelia Sipahelut
}

SMA Negeri 1 Sentani; corneliasipahelut@gmail.com

\begin{abstract}
This study aims to develop a problem-based biology module to improve higher-order thinking skills in Animalia material. The design used is an equivalent type of pre test post test design. The research sample consisted of 32 students of class X SMA Negeri 1 Sentani who used modules. The results showed that the use of modules can improve high-order thinking skills and the overall average n-Gain is 0.73 with high categories.
\end{abstract}

Keywords: Development of Modules; high level thinking; Animalia

\begin{abstract}
ABSTRAK
Penelitian ini bertujuan mengembangkan modul biologi berbasis masalah untuk meningkatkan keterampilan berpikir tingkat tinggi pada materi animalia. Desain yang digunakan adalah jenis one equivalen pre test post test design. Sampel penelitian berjumlah 32 peserta didik kelas X SMA Negeri 1 Sentani yang menggunakan modul. Hasil penelitian menunjukkan bahwa penggunaan modul dapat meningkatkan keterampilan berpikir tingkat tinggi dan n-Gain rata-rata secara keseluruhan sebesar 0,73 dengan katergori tinggi.
\end{abstract}

Kata Kunci : Pengembanan Modul; berpikir tingkat tinggi; Animalia

\section{PENDAHULUAN}

Kunci keberhasilan suatu bangsa untuk maju dan memperbaiki kehidupan masyarakatnya kearah yang lebih baik, adalah melalui Pendidikan. Menurut Setyawati (2013:16) Salah satu upaya dalam meningkatkan mutu pendidikan adalah dengan melakukan berbagai inovasi dalam kurikulum, salah satunya adalahdengan memasukkan pendidikan kecakapan hidup atau life skill, soft skill, Literasi, keterampilan berpikir tingkat tinggi dan pendidikan berkarakter. Oleh karena itu memajukan pendidikan sangat penting dan harus dilaksanakan.

Animalia adalah nama kingdom atau kerajaan bagi hewan yang kemudian diklasifikasikan berdasarkan ciri, stuktur, reproduksi dan peranan dalam kehidupan manusia. Kingdom/kerajaan animalia dibedakan menjadi hewan tidak bertulang belakang (invertebrate) dan hewan bertulang belakang (vertebrata). Dalam mempelajarinya cukup sulit sehingga perlu adanya konsep dan strategi yang tepat dan menarik dan berkaitan dengan kehidupan yang nyata sehari - hari. 
Model pembelajaran yang digunakan harus mencerminkan langkahlangkah yang sistematis, tersusun rapih dan logis sehingga tujuan dapat tercapai. Salah satu strategi pembelajaran yang dapat digunakan adalah dengan menerapkan pembelajaran berbasis masalah. Menerut Rusman (2012;76) Model pembelajaran berbasis masalah merupakan salah satu pendekatan atau Model pembelajaran yang digunakan untuk merangsang keterampilan berpikir tingkat tinggi peserta didik dalam situasi yang berorientasi pada masalah dunia nyata, dan terjadi dalam kehidupan sehari - hari, dengan maksud untuk dapat menyusun pengetahuan sendiri, mengembangkan kemandirian dan percaya diri. Sedangkan tugas guru adalah mengorientasikan peserta didik pada masalah yang autentik dan memfasilitasinya. Hal ini sesuai dengan harapan kompetensi abad 21 yaitu keterampilan berpikir kritis, kreatif, kolaboratif dan komunikatif, maka dibutuhkan keterampilan berpikir tingkat tinggi.

Menurut Ernawati

keterampilan berpikir tingkat tinggi atau Higher Order Thinking Skills (HOTS) merupakan cara berpikir yang tidak hanya menghafal secara verbalistik saja namun juga memaknai hakikat dari apa yang terkandung didalamnya, diantaranya untuk mampu memaknai sesuatu maka dibutuhkan cara berpikir yang integralistik dengan analisis, sintesis, mengasosiasi hingga menarik kesimpulan menuju penciptaan ide-ide kreatif dan produktif. Berpikir kritis diharapkan dapat meningkatkan hasil belajar peserta didik, karena peserta didik diajak untuk mempelajari materi animalia tidak dengan hanya menghafal konsep-konsep melainkan lebih dari itu yaitu dengan melibatkan aspek-aspek kognitif lainnya seperti afektif, analisis, sintesis dan evaluasi. Dengan demikian maka keterampilan berpikir tingkat tinggi perlu dilakukan dalam proses pembelajaran.

Bahan ajar yang disusun secara sistematis dengan bahasa yang mudah dipahami oleh peserta didik, sesuai usia dan tingkat pengetahuan peserta didik agar dapat belajar secara mandiri dengan bimbingan minimal dari pendidik disebut modul ( Prastowo: 2012). Artinya dengan menggunakan modul peserta didik dapat belajar secara mandiri tanpa bergantung pada teman serta dapat belajar sesuai dengan kemampuannya. Salah satu karakteristik modul menurut Lestari (2013) modul hendaknya bersahabat dengan pemakainya. Artinya perintah atau arahan dan paparan informasi yang tampil bersifat membantu dan bersahabat dengan pemakainya, termasuk kemudahan pemakai dalam merespon, mengakses sesuai dengan keinginan, penggunaan bahasa yang sederhana, mudah dimengerti serta menggunakan istilah yang umum 
digunakan. Hal inilah yang menjadi dasar mengapa perlu mengembangkan modul.

Berdasarkan Pengalaman dan obsevasi penulis bahwa di SMA Negeri 1 Sentani modul biologi materi animalia berbasis masalah belum tersedia, hasil ujian semester yang diperoleh peserta didik belum mencapai Kriteria ketuntasan minimal (KKM), hasil ujian nasional tiga tahun terakhir tidak mencapai kriteria ketuntasan sehingga penulis tertarik meneliti judul "Pengembangan Modul Biologi Materi Animalia melalui Pembelajaran Berbasis Masalah untuk Meningkatkan Keterampilan Berpikir Tingkat Tinggi Kelas X SMA Negeri 1 Sentani”.

\section{METODE PENELITIAN}

Penelitian ini adalah penelitian pengembangan modul pembelajaran Biologi berbasis masalah. Menurut Sugiyono (2015) desain eksperimen yang digunakan pada uji lapangan maupun pada uji coba satu-satu, uji coba kelompok kecil dan uji coba kelas adalah One Group Pretest-Postest Design, (Gambar 1) yang terdiri dari satu kelompok eksperimen tanpa kontrol.

Pengujian produk ini dilakukan dengan cara membandingkan dengan keadaan sebelum menggunakan dan sesudah menggunakan modul animalia.

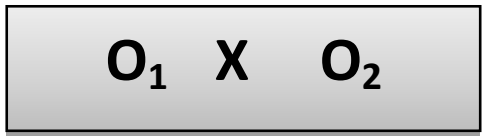

(Sugiyono, 2009)

Gambar 1: Desain eksperimen Pre test dan post test

Keterangan :

$\mathbf{O}_{1}$ menyatakan pre test, $\mathbf{O}_{2}$ menyatakan post test dan $\mathbf{X}$ menyatakan Treatment berupa penerapan modul

\section{Instrumen Pengumpulan Data}

Instrumen pengumpulan datapada penelitian ini berupa instrument non tes (angket), instrument tes, diskusi dan wawancara.

1. Instrumen non tes (Angket)

Angket adalah teknik pengumpulan data dengan cara memberi seperangkat pertanyaan atau pertanyaan tertulis kepada responden untuk dijawabnya. Tujuan penyebaran angket ialah untuk mengumpulkan informasi yang lengkap mengenai suatu masalah dan responden menjawab, dengan tidak merasa kuatir bila memberikan jawaban yang tidak sesuai dengan kenyataan dalam pengisian daftar pertanyaan. Angket digunakan sebagai lembar penilaian produk untuk mendapat data tentang isi, aspek kebahasan, aspek penyajian data dan aspek kegrafikan. Angket juga diperuntukkan untuk ahli materi dan ahli media. Jika dipandang dari segi bentuknya angket (kuesioner) yang akan dilakukan dalam bentuk skala likert (Sugiyono 2015). Angket dapat berupa pertanyaan tertutup dan pertanyaan 
terbuka, yang diberikan kepada responden secara langsung.

\section{Diskusi dan wawancara}

Diskusi dan wawancara terhadap guru mata pelajaran biologi kelas $\mathrm{X}$ tentang materi animalia yang bertujuan untuk mengetahui informasi tentang karakteristik pembelajaran dan model pembelajaran yang digunakan selama ini. Instrumen Diskusi dan wawancara ini juga ditujukan bagi peserta didik, yaitu peserta didik kelas X IPA ${ }^{3}$.

\section{HASIL DAN PEMBAHASAN}

Berdasarkan hasil uji n-Gain ratarata pada pertemuan RPP I, RPP II dan RPP III diperoleh nilai $n$-Gain rata-rata sebesar 0,73 dengan kategori tinggi, artinya sangat efektif untuk meningkatkan pemahaman peserta didik terhadap penguasaan materi animalia. Uji n-Gain seluruhnya terlihat pada Gambar 1 berikut ini.

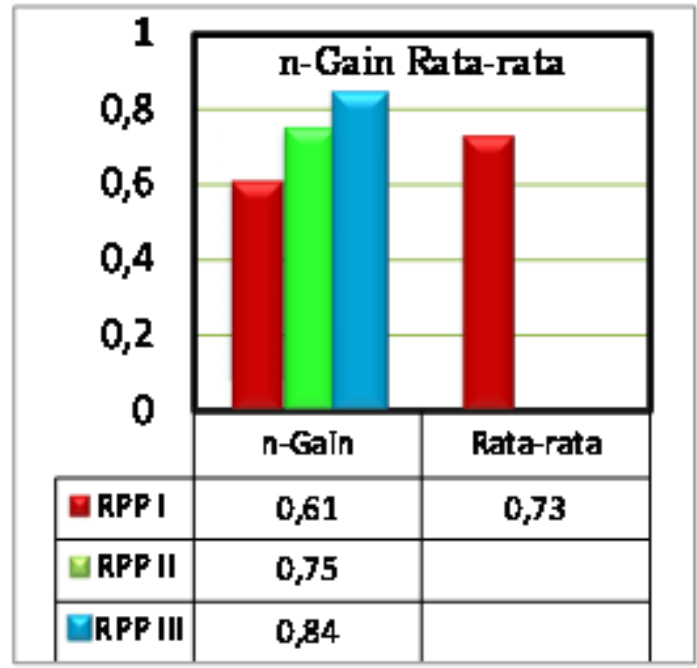

Gambar 1 Diagram batang n-Gain rata-rata tiap RPP.
Berdasarkan gambar 1 menunjukkan rata-rata $\mathrm{n}$ Gain sebesar 0,73 dengan kategori tinggi, ini berarti pembelajaran dengan modul sangat efektif meningkatkan pemahaman dalam pembelajaran biologi materi animalia berbasis masalah.

Penggunaan modul biologi materi animalia dengan menerapkan pembelajaran berbasis masalah, memberikan daya tarik tersendiri bagi peserta didik dalam menerapkan prinsip klasifikasi untuk menggolongkan animalia kedalam filum berdasarkan ciri-ciri. Data angket pada penilitian ini merupakan data pendukung dengan tujuan untuk melihat tanggapan peserta didik terhadap proses pembelajaran dengan menggunakan modul. Berdasarkan hasil presentasi tanggapan peserta didik di peroleh $90 \%$ memberikan tanggapan bahwa pembelajaran di kelas menyenangkan, sedangkan $10 \%$ menyatakan tidak menyenangkan, $90 \%$ siswa memberi tanggapan positif terhadap penggunaan modul pembelajaran dengan menjawab setuju sedangkan $10 \%$ memberi tanggapan negatif menjawab tidak setuju, $85 \%$ peserta didik memberi tanggapan positif terhadap lembaran aktivitas peserta didik yaitu menjawab setuju, $15 \%$ peserta didik memberi tanggapan dengan menjawab tidak setuju.

Berdasarkan data tersebut disimpulkan bahwa respon peserta didik terhadap pembelajaran dengan 
menggunakan modul sangat baik. Sedangkan dari hasil wawancara terhadap 5 orang peserta didik memberikan pernyataan positif terhadap pembelajaran dengan menggunakan modul yaitu : mudah digunakan, mudah untuk dipahami, mudah dalam mengerjakan soal karena dilengkapi dengan kunci jawaban, dan bahasa yang digunakan sederhana serta mendorong keterampilan berpikir tingkata tinggi.

Hasil pertemuan 1, 2, dan 3 menunjukkan keterlaksanaan pembelajaran dengan menggunakan modul animalia berbasis masalah di kelas X IPA SMA negeri 1 Sentani.Uji coba dilakukan pada kelas sampel yaitu kelas $\mathrm{X} \operatorname{IPA}^{3}$ sebagai kelas eksperimen dengan jumlah 32 orang pesetra didik, eksperimen dilakukan dengan pembelajaran yang menggunakan modul.

Untuk melihat hasil peningkatan penguasaan materi dilakukan uji n-Gain terhadap data hasil pre-test dan post-test untuk seluruh materi animalia. Hasil pretest dan post-test pada setiap pertemuan mengalami peningkatan. Pada pertemuan petama (RPP I) nilai n_Gain yang diperoleh adalah 0.61 dengan kategori sedang. Pertemuan dua (RPP II) nilai n_Gain adalah 0,75 dengan kategori tinggi, dan pertemuan ketiga (RPP III) dengan nilai n_Gain adalah 0,84 dengan kategori tinggi. Berdasarkan hasil analisis keseluruhan diperoleh $\mathrm{n}$-Gain rata-rata sebesar 0,73 yang termasuk dalam kategori tinggi. Hal ini senada hasil penelitian dari Tiurlina Siregar, Desry (2019) bahwa modul dapat meningkatkan hasil belajar kimia dan selanjutnya oleh Sri Lestari, dkk (2019) bahwa modul IPA terpadu dapat meningkatkan hasil belajar dilihat dapat meningkatkan n-Gain rata-ratanya. Hal ini membuktikan bahwa pembelajaran dengan menggunakan modul animalia berbasis masalah dapat meningkatkan hasil belajar peserta didik di SMA Negeri 1 Sentani.

\section{SIMPULAN DAN SARAN \\ SIMPULAN}

Penggunaan modul biologi materi animalia berbasis masalah dapat meningkatkan keterampilan berpikir tinggkat tinggi peserta didik sebesar 0,73 dengan kategori tinggi.

\section{SARAN}

Agar modul biologi dapat dibuat untuk meningkatkan keterampilan berpikir tingkat tinggi biologi pada materi yang lain.

\section{UCAPAN TERIMAKASIH}

Kepada sekolah SMA Negeri 1 sentani yang telah memberi distribusi dalam penelitian ini.

\section{DAFTAR PUSTAKA}

Ernawati, L. 2017, Pengembangan High Order Thinking (HOT) Melalui Metode Pembelajaran Mind Banking Dalam Pendidikan Agama Islam.PROCEEDINft, 189. diakses melalui http://bit.ly/2k66VLI pada tanggal 2 November 2018; 
Ika Lestari, 2013.Pengembangan Bahan Ajar Berbasis Kopetensi. Padang: Akademia Permata;

Andi Prastowo,2012, Panduan Kreatif membuat Bahan Ajar Inovatif. Yogyakarta: Diva Press;

Rusman,2012,Model-Model Pembelajaran, Jakarta : PT.Raja Grasindo Persada;

Setyawati, 2013, Pengembangan Perangkat Pembelajaran Aktif Strategi Giving Question and Getting Answer Terhadap Hasil Belajar Siswa Kelas XI TAV pada Standar Kompetensi Membuat Rekaman Audio Di Studio di SMK Negri 3 Surabaya. Jurnal. Surabaya: Fakultas Tekhnik Universitas Negri Surabaya.https://jurnalmahasiswa.un esa.ac.id/index.php/jurnalpendidikan-teknikelektro/article/view/919/680;
Sri Lestari, Tiurlina Siregar dan Jonner Nainggolan, 2019, Pengembangan Modul IPA Terpadu Berbasis Kearifan Lokal Papua Materi Interaksi Mahluk Hidup Terhadap Lingkungan, Jurnal Ilmu Pendidikan Indonesia, Vol 7 (3) 106 - 112;

Sugiyono, 2015, Metodologi Penelitian Kuantitatif Kualitatif dan $R \& D$, Bandung: Alfabet;

Tiurlina Siregar dan Desry Natalia, 2019, Modul PemBelajaran Inkuiri Terbimbing Pada Materi Larutan Elektrolit Dan Non Elektrolit, Jurnal Ilmu Pendidikan Indonesia, Vol 7 (1) $6-16$. 